\title{
Antibacterial activity and chemical compounds of leaves and branches of Protium hebetatum
}

\begin{abstract}
CONRADO, G.G.; SIMPLICIO, F.G²; COSTA, K.R.C; REHDER, V.L.G'; ESPINAR, M.F.4; SOUZA, G.O.2; SAMPAIO, P.T.B. ${ }^{5}$

1Divisão de Química Orgânica e Farmacêutica, Centro Pluridisciplinar de Pesquisas Químicas, Biológicas e Agrícolas-CPQBA, Rua Alexandre Cazelatto, 999, Vila Betel, CEP13081-970, Paulínia-SP, gabrielly_conrado@

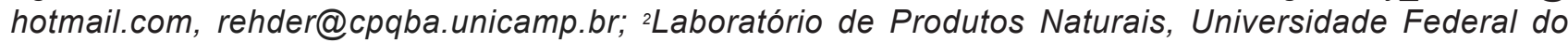
Amazonas, Rua Alexandre Amorim, 330, Aparecida, CEP 69103-00, Amazonas-AM, fgsfarmaceutica@gmail. com, chanderleitavares@yahoo.com.br; '3aboratório de Microbiologia, Universidade Federal do Amazonas, Rua Afonso Pena, 1053, Centro, CEP 69020-160, Amazonas-AM, costa.krc@gmail.com; ‘Laboratório de Produtos Naturais, Instituto Nacional de Pesquisas da Amazônia, Av. André Araújo, 2.936, Petrópolis, CEP 69067-375, Amazonas-AM, matefa5@hotmail.com; '5aboratório de Propagação de Plantas, Instituto Nacional de Pesquisas da Amazônia; Av. Efigênio Sales, 2239, Aleixo, CEP 69067-375, Amazonas-AM, sampaio@inpa. gov.br. *fgsfarmaceutica@gmail.com.
\end{abstract}

\begin{abstract}
The extracts and fractions of leaves and branches of Protium hebetatum D. C. Daly (Burseraceae) were investigated for their antibacterial activity and chemical composition. The methanol extract of branches (EMG) was considered active against the Escherichia coli and the Proteus vulgaris, showing an inhibition zone of $13 \mathrm{~mm}$, and was selected for bioassayguided phytochemical fractionation. From the technique of broth microdilution, the extract was considered a moderate inhibitor against Staphylococcus aureus, Pseudomonas aeruginosa and Enterococcus faecalis, with a minimum inhibitory concentration (MIC) of $1 \mathrm{mg} / \mathrm{mL}$. The dichloromethane fraction was considered a moderate inhibitor against $\mathrm{S}$. aureus (MIC of 1 $\mathrm{mg} / \mathrm{mL}$ ) and a potent inhibitor against $\mathrm{E}$. faecalis (MIC of $0.5 \mathrm{mg} / \mathrm{mL}$ ). F1, F2, F5 and F6 from chromatographic column of dichloromethane fraction were considered moderate inhibitors against $\mathrm{S}$. aureus (MIC of $1 \mathrm{mg} / \mathrm{mL}$ ). Through analysis by a gas chromatography mass spectrometry, eighteen compounds were identified, from which thirteen (isoeugenol, p-vinylguaiacol, metoxyeugenol, coumarin, 5-hydroxy-scopoletin, 4,7-dihydroxy-6-metoxicromam-2-one, 4[(1E]3-hydroxy-1-propenyl)-2-methoxyphenol, piperonal, scoparon, o-guaiacol, spathulenol, seringol and antiarol) are unprecedented in these species. We also identified the triterpenes $\alpha$-amyrin and $\beta$-amyrin, the steroids stigmasterol and sitosterol and the coumarin scopoletin, which was closely linked to the antibacterial activity of the samples.
\end{abstract}

Keywords: Protium hebetatum; antibacterial activity, coumarins, Staphylococcus aureus, Enterococcus faecalis.

RESUMO: Atividade antibacteriana e compostos químicos de folhas e galhos de Protium hebetatum. Extratos e frações de folhas e galhos de Protium hebetatum D. C. Daly (Burseraceae) foram investigados quanto sua atividade antibacteriana e composição química. O extrato metanólico dos galhos (EMG) foi considerado ativo contra Escherichia coli e Proteus vulgaris, apresentando um halo de inibição de $13 \mathrm{~mm}$, sendo selecionado para um fracionamento fitoquímico biomonitorado. A partir da técnica de microdiluição em caldo o EMG foi considerado um inibidor moderado contra Staphylococcus aureus, Pseudomonas aeruginosa e Enterococcus faecalis, apresentando uma concentração inibitória mínima (CIM) de $1 \mathrm{mg} / \mathrm{mL}$. A fração diclorometânica foi considerada inibidora moderada contra $S$. aureus (CIM de $1 \mathrm{mg} /$ $\mathrm{mL}$ ) e inibidora potente contra $E$. faecalis (CIM de $0,5 \mathrm{mg} / \mathrm{mL}$ ). F1, F2, F5 e F6 provenientes da fração diclorometânica foram consideradas inibidoras moderadas contra $S$. aureus (CIM de $1 \mathrm{mg} / \mathrm{mL}$ ). Através da análise por cromatografia gasosa acoplada a espectrometria de massa, foram identificados dezoitos compostos, dos quais treze (isoeugenol, $p$-vinilguaiacol,

Recebido para publicação em 28/09/2014

Aceito para publicação em 12/02/2015

10.1590/1983-084X/14_123

Rev. Bras. PI. Med., Campinas, v.17, n.4, supl. II, p.865-874, 2015. 
metoxieugenol, cumarina, 5-hidroxi-escopoletina, 4,7-dihidroxi-6-metoxicromam-2-ona, 4[(1E]3-hidroxi-1-propenil)-2-methoxifenol, piperonal, escoparona, o-guaiacol, espatulenol, seringol e antiarol) foram identificados pela primeira vez nesta espécie. Foram também identificados os triterpenos $\alpha$-amirina e $\beta$-amirina, os esteroides estigmasterol e sitosterol e a cumarina escopoletina, que estão intimamente ligados à atividade antibacteriana da espécie.

PALAVRAS-CHAVE: Protium hebetatum, atividade antibacteriana, cumarinas, Staphylococcus aureus, Enterococcus faecalis.

\section{INTRODUCTION}

Among the numerous species of plants used in popular medicine in Brazil, the species of the Protium genus are noteworthy, as this is the largest and most heterogeneous of the Burseraceae family, with about 150 species, $80 \%$ of which occur in the North of country, where a large portion of the Amazon rainforest is located (Siani et al., 2004). Species of the Burseraceae family are characterized by their resin exudate, popularly known as "breus", widely used in local popular medicine for its antiinflammatory, analgesic, expectorant, wound-healing and insect repellent properties (Bandeira et al., 2002; Maia et al., 2000), besides being used as fixative in artistic inks and in the manufacture of cosmetics, toiletries and perfumes (Ramos et al., 2000).

The extensive popular use of these species has promoted several scientific studies, which have intensified in recent years, leading to the identification of several interest pharmacological substances (Costa et al., 2012), as well as evidence of various therapeutic activities. Based on the ethnomedicinal use, it was found that ethyl ether extract of the resin of Protium kleinii showed excellent results its potent anti-inflammatory activity in topical use (Otuki et al., 2005). Pharmacologic studies with triterpenes $\alpha$ and $\beta$-amyrin isolated from extracts of the leaves and resin of species $P$. heptaphyllum demonstrated analgesic (Holanda Pinto et al., 2008), anti-inflammatory (Susunaga et al., 2001), antidepressant (Aragão et al., 2006), gastroprotective (Oliveira and Amaral, 2004) and cytotoxic (Taylor et al., 2012) activities. Another study with $P$. glabrescens resin demonstrated potent antimalarial activity for the species (Deharo et al., 2001).

In terms of chemical constitution, the literature reports the presence of triterpenes in resins of $P$. grandifolium and $P$. subserratum, and in bark and stem extracts of $P$. paniculatum and $P$. hebetatum, respectively, and the presence of steroids and coumarins in extract of $P$. hebetatum. Overall, triterpenes represent the most frequently occurring class of natural substances in the Protium genus (Costa et al., 2012; Silva et al., 2009; Zoghbi et al., 1993). Nevertheless, their antibacterial potential has been poorly investigated. A study of the essential oils extracted from the leaves, fruits, stems and bark of $P$. confusum showed that the essential oil extracted from the leaves demonstrated the best antibacterial activity against Staphylococcus aureus and Mycobacterium smegmatis (Santana et al., 2009). On the other hand, Protium hebetatum D. C. Daly, in which triterpenes and coumarins were previously identified, has not yet been investigated with this approach.

It is known than the continuous emergence of new mechanisms of bacterial resistance has generated a rush of pharmaceutical industries for the production and launch of new antimicrobial compounds that act by a different action mechanism drugs in use (Bérdy, 2012). Natural products and derived drugs have been crucial for the discovery of anti-infection drugs, and many of the antibacterial drugs currently in clinical use are natural products, or were designed using natural products as templates (Mishra and Tiwari, 2011).

Thus, considering the urgency of the search for new drugs for the treatment of bacterial infections, and the recognized antimicrobial activity of various plant extracts, this study conducted a bioassayguided phytochemical study of antibacterial activity of extracts and fractions obtained from leaves and branches of the species Protium hebetatum against bacteria of medical interest, seeking to identify substances with antibacterial activity, as alternatives to the present therapeutic arsenal.

\section{MATERIALS AND METHODS Chemicals}

Hexane, ethyl acetate, dichloromethane (Nuclear), methanol (Vetec) and equipment were provided of the Natural Products Laboratory of the Universidade Federal do Amazonas (UFAM). All other chemicals used in this experiment were purchased from the local chemical suppliers in Manaus.

\section{Microorganism}

Standard strains Enterococcus faecalis 
CCCD-E002, Escherichia coli E004-CCCD, Klebsiella pneumoniae CCCD-K003, Salmonella enterica S001-CCCD, Staphylococcus aureus ATCC 25923, Proteus vulgaris CCCD-P002, Pseudomonas aeruginosa P004 CCCD were commercially obtained in lyophilized form from the company Didactic SP. The culture media was provided of the Microbiology Laboratory of the UFAM.

\section{Plant material}

The collection of vegetal samples was authorized by the Instituto Chico Mendes de Conservação da Biodiversidade (ICMBio), chaired by the Ministry of Environment of Federative Republic of Brazil, under registration number 415531. Leaves and branches of five individuals of Protium hebetatum were collected in the Reserva Florestal Adolpho Ducke Manaus - AM (forestry reserve), in the following code and coordinates: 1 (S $02^{\circ} 55^{\prime} 97^{\prime \prime}$ W 59 58'57", ALT 78 m), 2 (S 2 $55^{\circ} 93^{\prime \prime}$ W 59 $58^{\circ} 53^{\prime \prime}$, ALT 65 m), 3 (S 02 55'96" W 59 58'48", ALT 93 m), 4 (S 2 ${ }^{\circ} 55^{\prime} 96^{\prime \prime}$ W 59 $58^{\circ} 48^{\prime \prime}$, ALT 59 m), 5 (S 02 $55^{\prime} 97^{\prime \prime}$ W $59^{\circ} 58^{\prime} 47^{\prime \prime}$, ALT $72 \mathrm{~m}$ ), and taxonomically identified by Dr. Mike Hopkins of the Herbarium of the Instituto Nacional de Pesquisas da Amazonia - INPA, where a voucher specimen was deposited for each individual under numbers 251968, 251969, 251970, 251971 e 251972 , respectively.

\section{Preparation of extracts}

Leaves and branches (nodes and internodes) were dried at room temperature for 7 days followed by a period of 24 hours at $40^{\circ} \mathrm{C}$ in an oven (WHO, 2003), then pulverized using a mechanical grinder equipped with a $0.5 \mathrm{~mm}$ sieve. The extracts were obtained by maceration using $480 \mathrm{~g}$ leaves and 638 $\mathrm{g}$ of branches and portions of $500 \mathrm{~mL}$ of hexane (total of $7 \mathrm{~L}$ ), ethyl acetate (total of $6 \mathrm{~L}$ ) and methanol (total of $8 \mathrm{~L}$ ), in cycles of $15 \mathrm{~min}$, in an ultrasound bath (Ultrasonic Cleaner Unique ${ }^{\circledR}$ ), sequentially. The new portions of solvents were added to residue of the previous extraction and the polarity of the solvents was altered until the volumes described above were achieved. The solvents were eliminated in a rotary evaporator (IKA $₫ \mathrm{RV} 10$ rotaevaporator basic) with a pressure of $500 \mathrm{mmHg}$, at $45^{\circ} \mathrm{C}$ and $110 \mathrm{rpm}$, yielding the respective extracts, which were kept under refrigeration $\left(8^{\circ} \mathrm{C}\right)$ until the time of use (Simões et al., 2007).

\section{Fractionation from the methanolic extract of the branches of $P$. hebetatum}

Fractionation of the methanolic extract of the branches was performed by liquid-liquid partition (Collins et al., 2006). For this purpose, $35 \mathrm{~g}$ of the extract was solubilized in $500 \mathrm{ml}$ of methanol:water 1:1 and extracted with $400 \mathrm{~mL}$ of hexane, dichloromethane and ethyl acetate, sequentially. The fractions were dried in a rotary evaporator (IKA ${ }^{\oplus} \mathrm{RV} 10$ rotaevaporator basic), providing the following fractions: FHMEB, FDMEB and FEAMEB. The solvent residual fraction, hydromethanol (FHMEB) was eliminated using a spray dryer apparatus. In the second stage of fractionation, $480 \mathrm{mg}$ of FDMEB was fractionated by column chromatography (Collins et al., 2006) using a glass column of $(32 \mathrm{~cm}$ high and $2 \mathrm{~cm}$ diameter as support, and $40.31 \mathrm{~g}$ of silica gel 60 (70-230 mesh, VETEC) as stationary phase. The column was initially eluated with dichloromethane and ethyl acetate $(60: 40 \mathrm{v} / \mathrm{v})$, with a gradual increase in polarity toward $100 \%$ methanol. The obtained fractions were analyzed by thin layer chromatography (TLC) using silica gel 60 (ALUGRAM® Xtra SIL G, MachereyNagel) and grouped according to their similarities, totaling 10 subfractions.

\section{(PTLC) \\ Preparative Thin Layer Chromatography}

The separation of active substances from samples obtained in item 2.5, in the Bioautography test was performed by preparative thin layer chromatography (PTLC). Using micro-syringes, $0.5 \mathrm{~mL}$ of a solution at $10 \mathrm{mg} / \mathrm{mL}$ of each sample were applied to a plate of silica gel 60 of $8 \times 10 \mathrm{~cm}$ (ALUGRAM® Xtra SIL G, Macherey-Nagel), which was eluted with hexane and ethyl acetate $50: 50 \mathrm{v} / \mathrm{v}$. A portion of $1 \mathrm{~cm}$ of the plate was cut and revealed with sulfuric anisaldehyde solution, followed by heating in an oven at $100^{\circ} \mathrm{C}$ to visualize and calculate the retention factors of the spots. The regions corresponding to the spots in the untreated portion of the plate were then cut into small pieces and transferred to glass vials. The substances in silica were extracted with ethyl acetate with the aid of an ultrasound bath (Ultrasonic Cleaner Unique $\left.{ }^{\circledR}\right)$. The solutions were then filtered with cotton and dried in a rotary evaporator (IKA® RV10 basic rotaevaporator) and sent for gas chromatography analysis.

\section{Gas chromatography coupled to mass spectrometry (GC-MS) analyzes \\ The identification of active substances} was performed on a gas chromatograph Agilent, HP-6890 model equipped with a mass selective detector (HP-5975 model, Agilent) using a finjector = $250^{\circ} \mathrm{C}$; column $=110^{\circ} \mathrm{C}$; heating rate of $5^{\circ} \mathrm{C} \cdot \mathrm{min}^{-1} ;$; temperature to $280^{\circ} \mathrm{C}(26 \mathrm{~min})$; detector $=300^{\circ} \mathrm{C}$. Helium was used as carrier gas at a flow rate of 1 $\mathrm{mL}$ min-1. Mass selective detector was operated at $70 \mathrm{eV} / \mathrm{z}=40$ to 600 u.m.a. 


\section{Qualitative Test of antibacterial activity - Agar Diffusion}

The strains were initially hydrated in Brain Heart Infusion Broth (BHIB - Himedia) and incubated at $37^{\circ} \mathrm{C}$ for $24 \mathrm{~h}$ for reactivation. A small fraction of growth colonies was withdrawn and diluted in sterile saline solution $(0.9 \% \mathrm{NaCl})$ to obtain a standard inoculum of turbidity on a scale 0.5 to Mac Farland, equivalent to a final concentration of $1.0 \times 10^{8} \mathrm{CFU} /$ $\mathrm{mL}$ (NCCLS, 2003). Antibacterial tests of extracts and fractions of the $P$. hebetatum obtained by liquidliquid partition were performed in triplicate by the agar diffusion method, according to the protocol proposed by the Clinical and Laboratory Standards Institute (CLSI, 2009) with slight modifications. The microorganisms were inoculated in a laminar flow hood, where for each $25 \mathrm{~mL}$ of media MuellerHinton Agar (AMH - Himedia) molten, 500 $\mu \mathrm{L}$ of standard inoculum was added. After solidification of the agar, a circular cavity of $6 \mathrm{~mm}$ diameter were made, at points equidistant from the plate, to which was added $20 \mu \mathrm{L}$ of the extracts and partitions at a concentration of $4 \mathrm{mg} / \mathrm{mL}$ per well. Gentamicin at a concentration of $10 \mu \mathrm{g} / \mathrm{mL}$ was used as positive control and dimethylsulfoxide (DMSO) as solvent of the samples and negative control. The plates were incubated at $37^{\circ} \mathrm{C}$ for $24 \mathrm{~h}$. After the incubation period the antibacterial activity was determined by measuring the inhibition zone $(\mathrm{mm})$ and analyzed as follows (Alves et al., 2000): inactive $(<9 \mathrm{~mm})$, little active $(9-12 \mathrm{~mm})$, active $(13-18 \mathrm{~mm})$ and very active (> 18mm).

\section{Determination of Minimum Inhibitory Concentration (MIC) - Broth Microdilution}

The MIC was determined only for samples that showed activity in the well diffusion method and the fractions obtained from the FDEMG. The assays were performed by the micro-dilution (96 wells per plate) according to standard M7-A6 Manual of Clinical and Laboratory Standards Institute (CLSI, 2006) with slight modifications. The inoculates were standardized according to the $0.5 \mathrm{McF}$ arland scale and subjected to dilution in Mueller-Hinton Broth (HCM - Himedia) to achieve a final concentration of $1.5 \times 10^{4} \mathrm{CFU} / \mathrm{mL}$. Next, $100 \mu \mathrm{L}$ of culture medium with the bacterial inoculum and $100 \mu \mathrm{L}$ of sample in serial concentrations $(4 \mathrm{mg} / \mathrm{mL}, 2 \mathrm{mg} / \mathrm{mL}, 1 \mathrm{mg} / \mathrm{mL}$, $0.500 \mathrm{mg} / \mathrm{mL}, 0.250 \mathrm{mg} / \mathrm{mL} 0.125 \mathrm{mg} / \mathrm{mL}, 0.06 \mathrm{mg} /$ $\mathrm{mL}$ and $0.03 \mathrm{mg} / \mathrm{mL}$ ) were added to each well of the microplate. Wells were also prepared with growth control micro-organism, sterility of the medium, and positive control (gentamicin $10 \mu \mathrm{g} / \mathrm{mL}$ ). The plates were incubated at $37^{\circ} \mathrm{C}$ for $24 \mathrm{~h}$ for later verification of microbial growth. After the incubation period, 20 $\mu \mathrm{L}$ of resazurin developer $(10 \mathrm{mg} / \mathrm{mL}$ ) was added to each well of the microplate. The microplates are reincubated for a period of $3 \mathrm{~h}$ and analyzed for color change of the cultures, with blue indicating the absence of bacterial growth, and pink indicating the presence of bacterial growth (Palomino et al., 2002). The minimum inhibitory concentration was revealed by the lowest concentration that promoted growth inhibition, evidenced by the permanence of the original color, classifying samples with MIC up to $0.5 \mathrm{mg} / \mathrm{mL}$ as potent inhibitor samples, those with MIC of between 0.6 and $1.5 \mathrm{mg} / \mathrm{mL}$ as moderate inhibitors, and those with MIC above $1.6 \mathrm{mg} / \mathrm{mL}$ as weak inhibitors (Aligiannis et al., 2001).

\section{Bioautography}

To determine what substances were responsible for the antibacterial activity presented by F1, a screening test called Bioautography (Choma and Grzelak, 2011) was performed only against Staphylococcus aureus. Initially $30 \mu \mathrm{L}$ of the F1 was applied, with the aid of micropipettes, to silica gel 60 $\mathrm{CCM}^{\circledR}$ Xtra Alugram SIL G/UV254 chromatogram plates $(5.5 \times 3 \mathrm{~cm})$ and eluted with hexane and ethyl acetate $50: 50 \mathrm{v} / \mathrm{v}$. After 30 minutes, the duly dried chromatograms were placed in sterile Petri plates $(90 \times 15 \mathrm{~mm})$, to which were added $15 \mathrm{~mL}$ of $\mathrm{AMH}$ medium containing $300 \mu \mathrm{L}$ of the standard inoculum of $S$. aureus, suitably adjusted to a scale of 0.5 which is equivalent to the MacFarland final concentration of $1.0 \times 10^{8} \mathrm{CFU} / \mathrm{mL}$ and $600 \mu \mathrm{L}$ of an aqueous developer solution 2,3,5-triphenyltetrazolium chloride (TTC) at a concentration of $20 \mathrm{mg} / \mathrm{mL}$. After medium solidification, Petri plates were incubated at $37^{\circ} \mathrm{C}$ for $18 \mathrm{~h}$. After the incubation period, the inhibition zone (colorless points) were visualized against a red background on the plate surface, indicating the presence of antibacterial substances (Duarte et al., 2005).

\section{RESULTS AND DISCUSSION}

Antibacterial Activity of Protium hebetatum

We analyzed the antibacterial potential of the extracts hexane of the leaves (HEL, 1.38 $\%$ yield), ethyl acetate of the leaves (EaEL, 1.84 $\%$ yield), methanolic of the leaves (MEL, 11.09 $\%$ yield), hexane of the branches (HEB, $0.97 \%$ yield), ethyl acetate of the branches (EaEB, $1.14 \%$ yield) and methanolic of the branches (MEB, 6.07 $\%$ yield) using the agar diffusion technique against seven bacterial strains responsible for respiratory, gastrointestinal, urinary and skin infections, and that more frequently acquire antibiotic resistance (Bérdy, 2012). According to the measurement of inhibition zone, the MEB showed activity against Escherichia coli and Proteus vulgaris presenting inhibition zones of $13 \mathrm{~mm}$ in diameter. In other study, the essential oil from the leaves, fruits and stem of Protium

Rev. Bras. PI. Med., Campinas, v.17, n.4, supl. II, p.865-874, 2015. 
confusum presented activity against Staphylococcus aureus and Mycobacterium smegmatis (Santana et al., 2009). MEB was also active against Klebsiella pneumoniae, Enterococcus faecalis and Salmonella enterica, presenting inhibition zones of $11 \mathrm{~mm}$ in diameter. However, MEB was inactive for $S$. aureus and Pseudomonas aeruginosa. The other extracts were inactive against all bacteria tested (Table 1).

For the bioguided fractionation, we performed a liquid-liquid partition with MEB dissolved in methanol and water using hexane, dichloromethane and ethyl acetate, sequentially, yielding the hexane (FHMEB, $21.9 \%$ yield), dichloromethane (FDMEB, $1.43 \%$ yield), ethyl acetate (FEAMEB, $26.2 \%$ yield) and hydromethanol (FHyMEB, $42.55 \%$ yield) fractions, respectively. With these fractions, we performed a new antibacterial screening in the agar diffusion technique against same bacterial strains, against which EMG was tested. Among the fractions analyzed, the FDMEB showed activity against $S$. aureus, presenting inhibition zones with diameter of $13 \mathrm{~mm}$ and little activity against $E$. faecalis, presenting inhibition zones of $11.3 \mathrm{~mm}$ and inactivity for the remaining bacterial strains. All other fractions were inactive against all the bacteria tested (Table 2).

Fractionation of FDMEB by chromatographic column yielded 10 fractions, from which we determined the Minimum Inhibitory Concentration (MIC) against the bacteria used in the agar diffusion test. The MIC was also determined for MEB and FDMEB. MEB showed moderate inhibition for $S$. aureus, $E$. faecalis and $P$. aeruginosa, presenting MIC of $1000 \mu \mathrm{g} / \mathrm{mL}$, and weak inhibition for $K$. pneumoniae, S. enterica, E. coli and $P$. vulgaris, with MIC of $2000 \mu \mathrm{g} / \mathrm{mL}$ (Table 2).
As noted, MEB proved to be a moderate inhibitor against $P$. aeruginosa and $S$. aureus when tested by the microdilution method, but was inactive in the agar diffusion test. The agar diffusion technique is a qualitative test based on the diffusion of the samples in the medium. Therefore, it is possible that the lack of antibacterial activity against these bacteria is due to a lack of diffusivity of the extract. In this context, it is proposed that this variation may be justified by the chemical composition of the samples, since higher molecular weight molecules tend to be more soluble and dispersible in liquid medium than in solid medium (Valgas et al., 2007).

More than half of the fractions (F3, F4 and F7 - F10) presented as weak inhibitors, with MIC $\geq 2000 \mu \mathrm{g} / \mathrm{mL}$. However, FDMEB was a moderate inhibitor against $S$. aureus, presenting MIC of 1000 $\mu \mathrm{g} / \mathrm{mL}$, and a potent inhibitor against $E$. faecalis, presenting MIC of $500 \mu \mathrm{g} / \mathrm{mL}$. Fractions F1, F2, $\mathrm{F} 5$ and $\mathrm{F} 6$ also proved to be moderate inhibitors against $S$. aureus, with MIC of $1000 \mu \mathrm{g} / \mathrm{mL}$. However, although the MICs determined in this study are not as significant as for other species reported in the scientific literature, they are unpublished results on the biological potential of Protium hebetatum, adding relevant information to the scientific knowledge of the species.

Of all the active fractions, we selected only F1 for the follow up research, as it demonstrated an interesting profile of separation of substances in the analysis by thin layer chromatography (TLC), which is important for further fractionation. On the bioautography of $F 1$, the sample showed an inhibition zone around all the compounds present on the TLC plate, indicating that the same is rich

TABLE 1. Antibacterial activity of extracts and fractions of Protium hebetatum in the agar diffusion test

\begin{tabular}{|c|c|c|c|c|c|c|c|}
\hline \multirow[b]{2}{*}{ SAMPLES ${ }^{a}$} & \multicolumn{7}{|c|}{ MICROORGANISMS } \\
\hline & S. aureus & E. faecalis & K. pneumoniae & S. enterica & $P$ & E. coli & P. vulgaris \\
\hline HEL & - & - & - & - & - & - & - \\
\hline EAEL & - & - & - & - & - & - & - \\
\hline MEL & - & - & - & - & - & - & - \\
\hline HEB & - & - & - & - & - & - & - \\
\hline EAEB & - & - & - & - & - & - & - \\
\hline MEB & - & $11 \mathrm{~mm}$ & $11 \mathrm{~mm}$ & $11 \mathrm{~mm}$ & - & $13 \mathrm{~mm}$ & $13 \mathrm{~mm}$ \\
\hline FHMEB & - & - & - & - & - & - & - \\
\hline FDMEB & $13 \mathrm{~mm}$ & $11.3 \mathrm{~mm}$ & - & - & - & - & - \\
\hline FEAMEB & - & - & - & - & - & - & - \\
\hline FHyMEB & - & - & - & - & - & - & - \\
\hline GENTAMICIN & $17 \mathrm{~mm}$ & $17 \mathrm{~mm}$ & $17.5 \mathrm{~mm}$ & $20 \mathrm{~mm}$ & $27 \mathrm{~mm}$ & $29 \mathrm{~mm}$ & $15 \mathrm{~mm}$ \\
\hline DMSO a & - & - & - & - & - & - & - \\
\hline
\end{tabular}

(-) no inhibition zone was observed.

DMSO a - dimethylsulfoxide.

Rev. Bras. PI. Med., Campinas, v.17, n.4, supl. II, p.865-874, 2015. 
TABLE 2. MIC of the active fractions of Protium hebetatum

\begin{tabular}{cccccccc}
\hline \multirow{2}{*}{ SAMPLES } & \multicolumn{7}{c}{ MIC $(\boldsymbol{\mu g} / \mathbf{m L})$} \\
\cline { 2 - 8 } & S. aureus & E. faecalis & K. pneumoniae & S. enterica & P. aeruginosa & E. coli & P. vulgaris \\
\hline MEB & 1000 & 1000 & 2000 & 2000 & 1000 & 2000 & 2000 \\
FDMEB & 1000 & 500 & - & - & - & - & - \\
F1 & 1000 & 2000 & - & - & - & - & - \\
F2 & 1000 & 2000 & - & - & - & - & - \\
F3 & 2000 & 1000 & - & - & - & - & - \\
F4 & 2000 & 1000 & - & - & - & - & - \\
F5 & 1000 & 1000 & - & - & - & - & - \\
F6 & 1000 & 1000 & - & - & - & - & - \\
F7 & 2000 & 2000 & - & - & - & - & - \\
F8 & 2000 & 2000 & - & - & - & - & - \\
F9 & $>2000$ & $>2000$ & - & - & - & - & - \\
F10 & $>2000$ & $>2000$ & - & - & - & - & - \\
GENTAMYCIN & 10 & 10 & 10 & 10 & 10 & 10 & 10 \\
\hline
\end{tabular}

in bioactive substances. This also suggests that the antibacterial activity observed in MEB and its fractions are not due to a single active substance, but to a joint action of the compounds in the mixture, given that that the crude extract was quantitatively more active than the samples obtained from its fractionation, as indicated by the results of the agar diffusion test. Figure 1 shows the result of the bioautography of $\mathrm{F} 1$.

The pink spot (retention factor of 0.67 ) and the purple spot (retention factor of 0.64 ), both highlighted by brackets in Figure 2A, had good separation profile. Furthermore, it was active when stained with TCC (Fig. 2B). We performed the separation of these spots by preparative thin layer chromatography (PTLC), a simple, rapid and inexpensive technique that is frequently used to isolate substances with minimal yields. This technique led to two fractions, named $\mathrm{B} 1$ and $\mathrm{B} 2$, which along with fractions FDMEB, F1, F2, F3, F4 and $\mathrm{F} 5$, were analyzed by gas chromatography coupled with mass spectrometry (GC-MS) to identify the compounds.

\section{Chemical Composition of Protium hebetatum}

We analyzed the active samples in the screening of antibacterial activity by the GC-MS method and obtained mass spectra for each signal in the chromatogram, comparing these with the data from the NIST Mass Spectral Search Program version 2.0, available in the equipment used (Figure 2). We identified eighteen compounds, thirteen of which (isoeugenol, $p$-vinylguaiacol, methoxyeugenol, coumarin, 5-hydroxy-scopoletin, 4,7-dihydroxy-6-metoxicromam-2-one, 4-[(1E]-3-
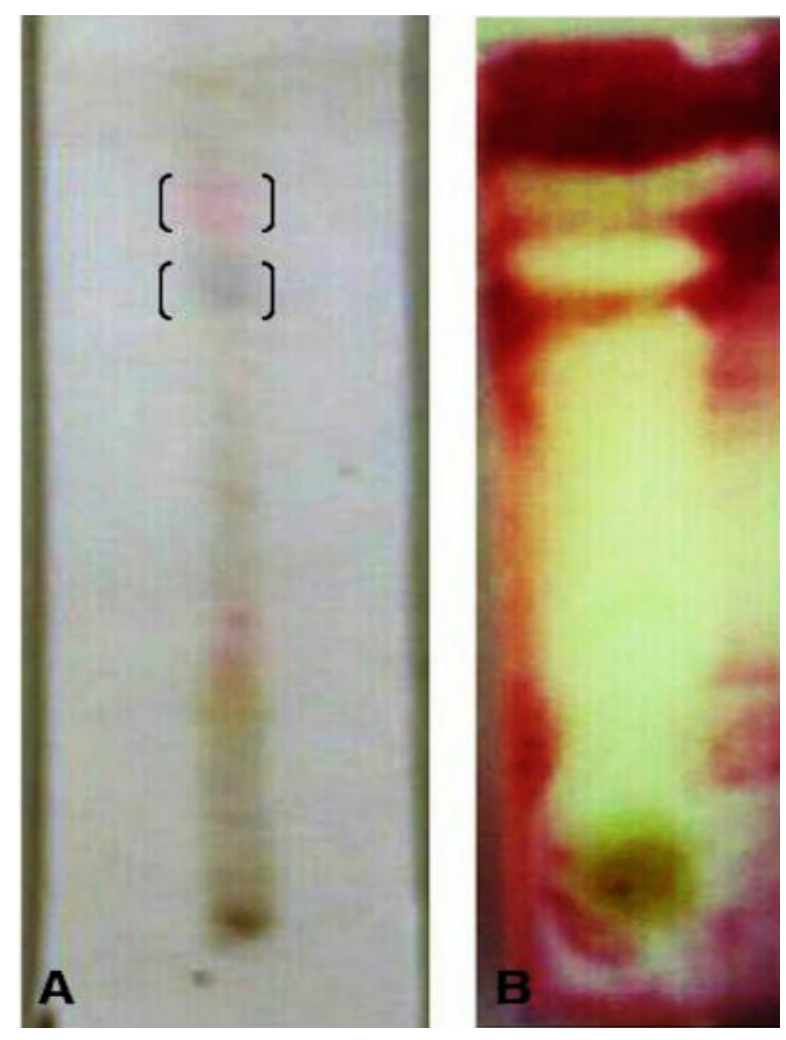

FIGURE 1. F1 antibacterial agents identified by the Bioautography method. (A) Plate revealed with sulfuric anisaldehyde solution; (B) Plate revealed with 2,3,5-triphenyltetrazolium chloride (TTC). Eluent: hexane: ethyl acetate 1:1.

hydroxy-1-propenyl)-2-methoxyphenol, piperonal, scoparon, o-guaiacol, spathulenol, seringol and antiarol) are unprecedented in this species (Table 3). 
TABLE 3. Compounds identified from the FDMEB and subsequent fractions

\begin{tabular}{|c|c|c|c|c|c|c|c|c|c|c|}
\hline Compounds & $\mathrm{Rt}^{\mathrm{a}}(\mathrm{min})$ & $\mathrm{M}^{\mathrm{b}}(\mathrm{g} / \mathrm{mol})$ & FDMEB ${ }^{c}$ & F1 & F2 & F3 & F4 & F5 & B1 & B2 \\
\hline o-Guaiacol & 3.577 & 124 & & & & & 1.44 & & & \\
\hline Coumarin & 4.932 & 120 & & & 3.65 & 11.01 & 6.84 & & & \\
\hline$\rho$-Vinylguaiacol & 6.592 & 150 & 1.79 & & 2.52 & 8.86 & 8.21 & 5.50 & & \\
\hline Piperonal & 9.987 & 150 & 0.52 & 2.33 & & & & & & \\
\hline Isoeugenol & 9.112 & 164 & 1.35 & 5.25 & 2.79 & 3.17 & 2.46 & 1.90 & & \\
\hline Antiarol & 12.286 & 184 & 0.30 & & & & & & & \\
\hline Methoxyeugenol & 14.277 & 194 & 0.57 & 1.70 & 0.85 & & 0.60 & & & \\
\hline Spathulenol & 14.768 & 220 & & & 1.71 & 6.83 & & & & \\
\hline $\begin{array}{l}4 \text { [(1E]-3-hydroxy-1-propenyl)-2- } \\
\text { methoxyphenol }\end{array}$ & 15.022 & 180 & 4.03 & & 1.92 & 17.19 & 34.95 & 36.47 & & \\
\hline$\beta$-Hydroxypropiovanillone & 16.562 & 196 & & & 6.04 & & & & & \\
\hline $\begin{array}{l}\text { 4.7-dihydroxy-6-metoxicromam- } \\
\text { 2-one }\end{array}$ & 17.376 & 208 & & & & 19.32 & & & & \\
\hline Scopoletin & 19.437 & 192 & 1.94 & 49.85 & 41.30 & & & & & \\
\hline Scoparon & 19.672 & 206 & & 2.10 & 6.18 & & & & & \\
\hline 5-hydroxy-scopoletin & 20.016 & 210 & 1.92 & & 4.80 & 13.73 & 29.73 & 1.92 & & \\
\hline Stigmasterol & 41.367 & 412 & 4.32 & & & & & & & 5.44 \\
\hline Sitosterol & 42.932 & 414 & 17.53 & & & & & & & 18.15 \\
\hline$\alpha$-amyrin & 43.842 & 426 & 11.61 & & & & & & 68.70 & \\
\hline$\beta$-amyrin & 45.216 & 426 & & & & & & & 31.30 & \\
\hline
\end{tabular}

${ }^{a} \mathrm{Rt}=$ Retention time; ${ }^{\mathrm{b}} \mathrm{M}=$ Molar mass; ${ }^{\mathrm{C}}$ Results expressed as \% of area
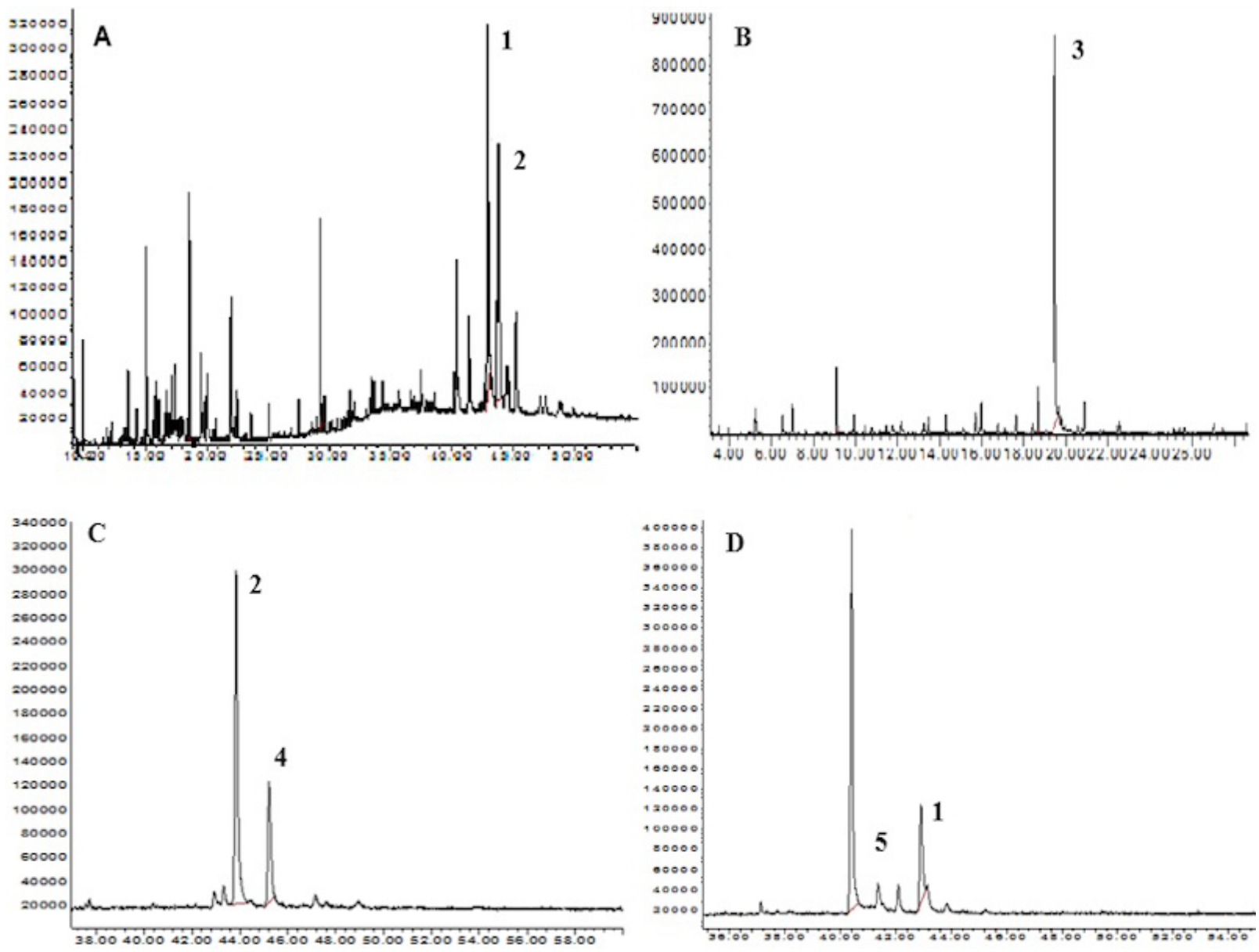

FIGURE 2. Chromatograms (GC-MS) of the active fractions obtained from MEB oh the $P$. hebetatum. AChromatogram of the FDMEB, (1) sitosterol, (2) a- amyrin; B - Chromatogram of the F1, (3) scopoletin; C Chromatogram of the B1, (2) $\alpha$ - amyrin, (4) $\beta$ - amyrin; D - Chromatogram of the B2, (1) sitosterol, (5) stimasterol. Other chromatograms and spectral data are available in the supplementary material. 
The compounds identified in sample B1 correspond to $\alpha$-amyrin and $\beta$-amyrin triterpenes, and the compounds identified in sample B2 correspond to stigmasterol and sitosterol steroids (Figure 2).

Among the compounds identified, isoeugenol (Santin et al., 2011), guaiacol, spathulenol (Cooper et al., 2013), $\alpha$ - and $\beta$-amyrin (Coloma et al., 2011) and scopoletin (Musa et al., 2011) have known antibacterial activity. There were higher percentage areas of coumarin, 5-hydroxyscopoletin, 4,7-dihydroxy-6-metoxicromam-2one and scopoletin, in the samples, and it is suggested that the antibacterial activity presented by MEB is attributed to this class of coumarins. This also means that Protium hebetatum is a potential source of coumarins, which have a wide range of industrial applications, including in the pharmaceutical industry.

This is a pioneering work on the evaluation of the antibacterial activity of Protium hebetatum. Its activity against Staphylococcus aureus and
Enterococcus faecalis is noteworthy, due to the impact of these microorganisms on public health, and its involvement in the etiology of various gastrointestinal disorders with high prevalence. Our results, particularly those relating to the identification of substances, motivate further scientific investigations of Protium hebetatum, focusing, for example, on its analgesic and anti-inflammatory activities due the presence of coumarins and triterpenes, as well as prompting studies with other species of genus Protium, which are still poorly studied. The GCMS analyses indicate that the species is rich in substances of industrial interest, such as isoeugenol, guaiacol, and scopoletin, which are widely used in the pharmaceutical, food, toiletries, cosmetics and agricultural industries.

\section{SUPPLEMENTARY MATERIAL}

Chromatograms (GC-MS) of the fractions obtained from MEB on P. hebetatum.

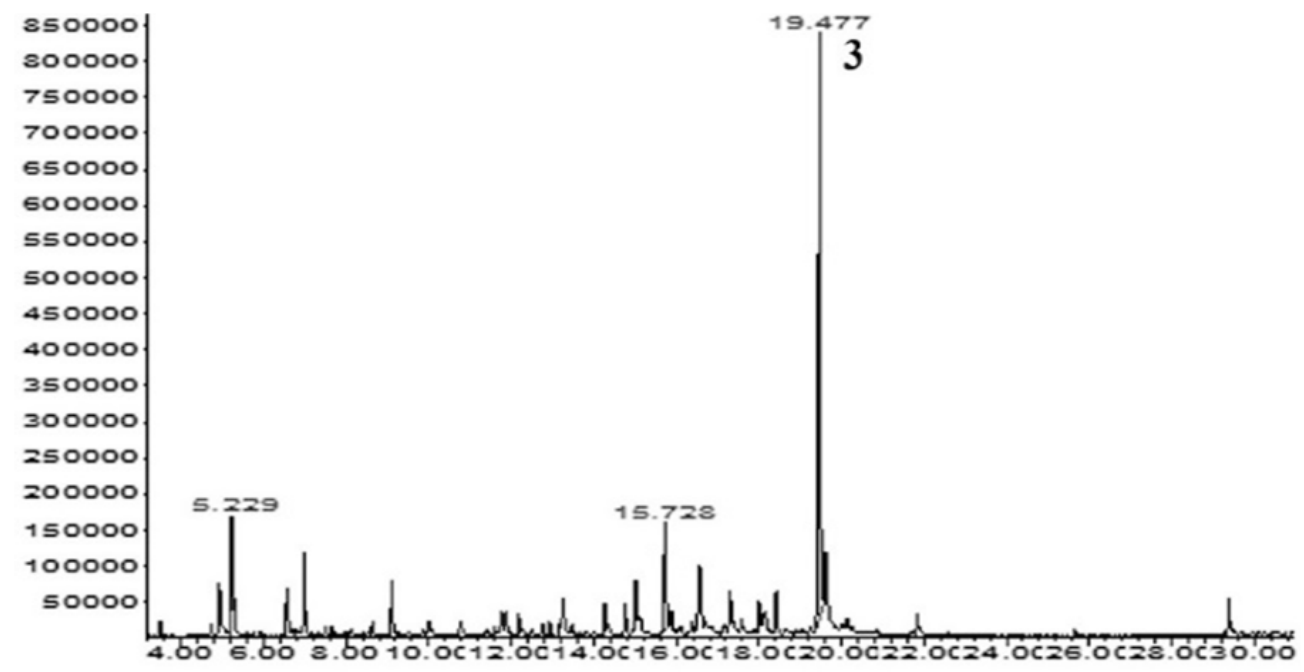

FIGURE 3. Cromatogram of the F2, (3) scopoletin

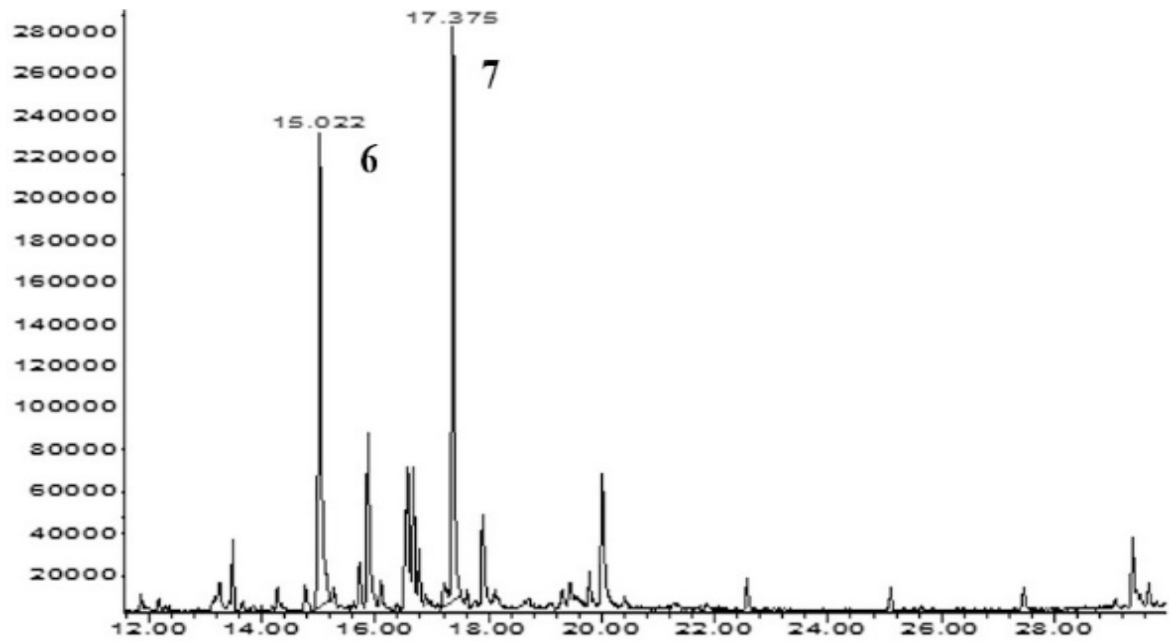

FIGURE 4. Cromatogram of the F3, (6) 4 [(1E]-3-hydroxy-1-propenyl)-2-methoxyphenol, (7) 4.7-dihydroxy-6metoxicromam-2-one

Rev. Bras. PI. Med., Campinas, v.17, n.4, supl. II, p.865-874, 2015. 


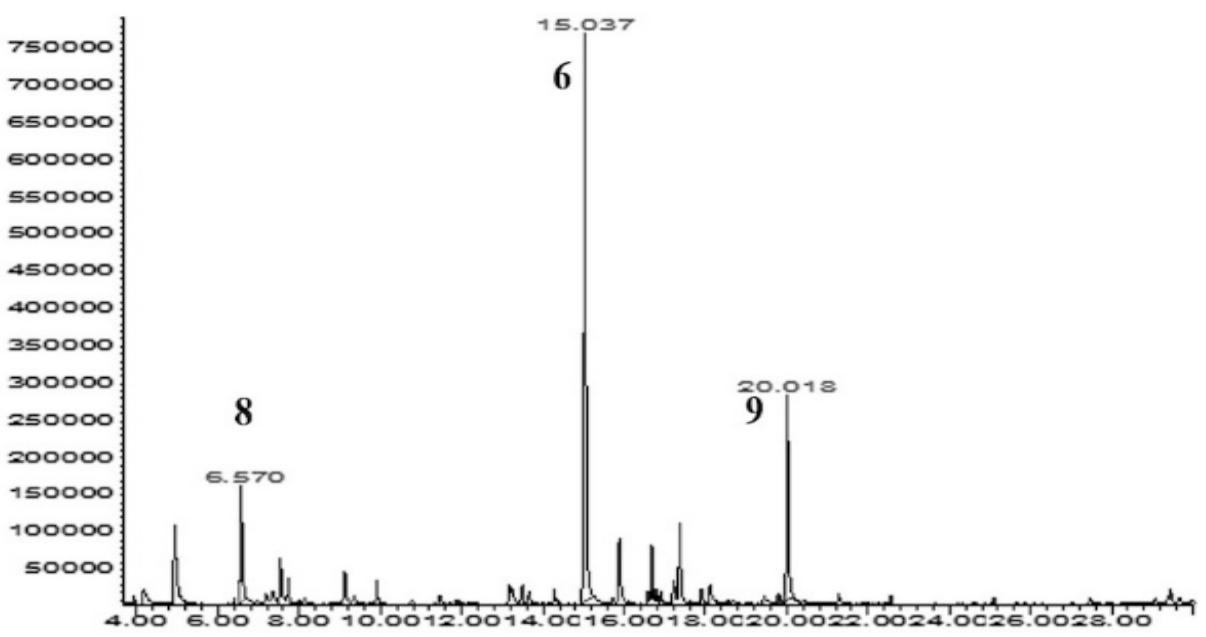

FIGURE 5. Cromatogram of the F4, (8) $\rho$-Vinylguaiacol, (6) 4 [(1E]-3-hydroxy-1-propenyl)-2-methoxyphenol, (9) 5-hydroxy-scopoletin

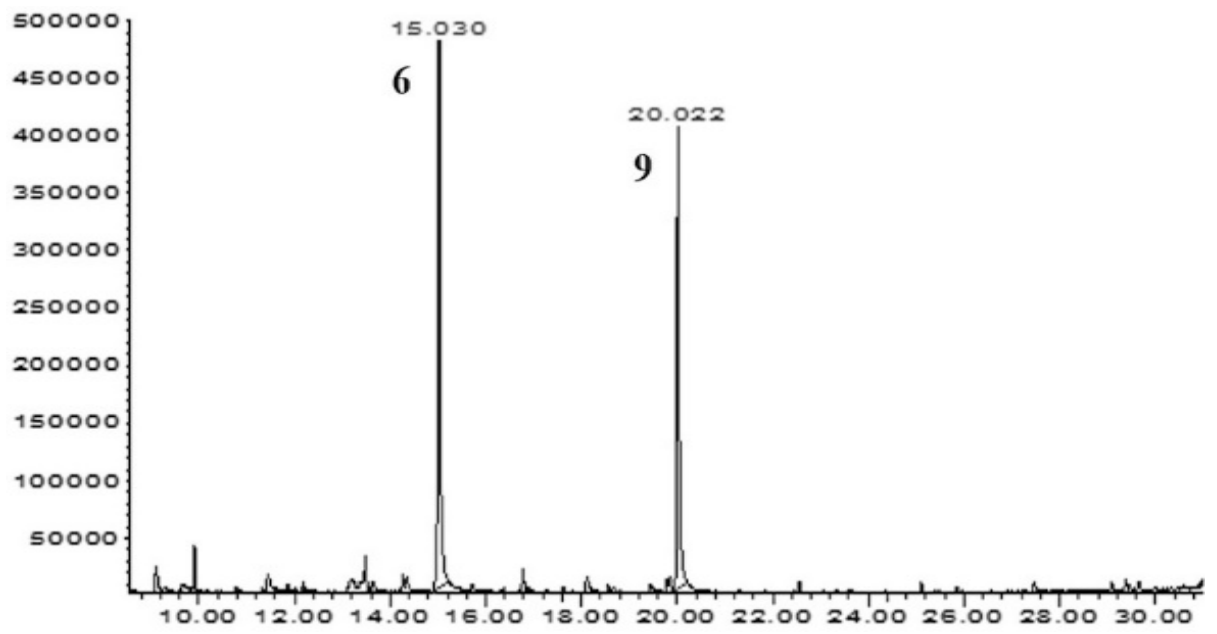

FIGURE 6. Cromatogram of the F5, (6) 4 [(1E]-3-hydroxy-1-propenyl)-2-methoxyphenol, (9) 5-hydroxy-scopoletin

\section{ACKNOWLEDGMENTS}

This research was supported by a grant from FAPEAM (AM, Brazil).

\section{REFERENCES}

ALIGIANNIS, N; KALPOTZAKIS, E; MITAKU, S; CHINOU, I.B. Composition and antimicrobial activity of the essential oils of two Origanum species. Journal of Agricultural and Food Chemistry, v.40, p.4168-4170, 2001.

ALVES, T.M.A.; SILVA, A.F.; BRANDÃO, M.; GRANDI, T.S.M.; SMÂNIA, E.F.; SMÂNIA, J.R.A.; ZANI, C.L. Biological screening of Brazilian medicinal plants. Memória Instituto Oswaldo Cruz, v. 95, p.367-373, 2000.

ARAGÃO, G.F.; CARNEIRO, L.M.V.; JUNIOR, A.P.F.; VIEIRA, L.C.; BANDEIRA, P.N.; LEMOS, T.L.G.; VIANA, G.S.B. A possible mechanism for anxiolytic and antidepressant effects of alpha- and beta-amyrin from
Protium heptaphyllum (Aubl) March. Pharmacology

Biochemistry \& Behavior, v.85, p.827-834, 2007.

BANDEIRA, P.N.; PESSOA, O.D.L.; TREVISAN, M.T.S.; LEMOS, T.L.G. Metabólitos secundários de Protium heptaphyllum March. Química Nova, v.25, p.10781080, 2002.

BÉRDY, J. Thoughts and facts about antibiotics: Where we are now and where we are heading. Journal of Antibiotics, v.65, p.385-395, 2012.

CHOMA I.M.; GRZELAK E.M. Bioautography detection in thin-layer chromatography. Journal of Chromatography A. v.1218, p.2684-2691, 2011.

CLSI. Manual Clinical and Laboratory Standards Institute. Methods for dilution antimicrobial susceptibility tests for bacteria that grow aerobically; approved standards- 6th ed. Document M7-A6 performance standards for antimicrobial susceptibility testing. Clinical and Laboratory Standards Institute, Wayne, PA, 2006.

CLSI. Performance Standards for Antimicrobial Disk Susceptibility Tests; 88 Approved Standard-Eighth 
Edition. CLSI document M2-A8 (ISBN 1-56238-4856). CCLS, 940 West Valley Road, Suite 1400, Wayne, Pennsylvania 19087-1898 USA, 2009.

COLLINS, C.H.; BRAGA, G.L.; BONATO, P.S. Fundamentos de cromatografia. Campinas: Editora da Unicamp, 456p, 2006.

COLOMA, A.G.; BALBOA, C.L.; REINA, O.S.M.; FRAGA, B.M. Triterpene based plant defenses. Phytochemistry, v.10, p.245-260, 2011.

COOPER, R.A. Inhibition of biofilms by glucose oxidase, lactoperoxidase and guaiacol: the active antibacterial component in an enzyme alginogel. International Wound Journal, v.37, p.373-376, 2013.

COSTA, T.O.G.; ALMEIDA, R.A.; KOOLEN, H.H.F.; SILVA, F.M.A.; PINTO, A.C. Constituintes químicos do caule de Protium hebetatum (Burseraceae). Acta Amazônica, v.42, p.557-560, 2012.

DEHARO, E.; BOURDY, G.; QUENEVO, C.; MUNOZ, V.; RUIZ, G.; SAUVAINA, M. A search for natural bioactive compounds in Bolivia through a multidiscipilinary approach. Part V. Evolution of antimalarial activity of plants used by Tacana Indians. Journal of Ethnopharmacology, v.77, p.91-98, 2001.

DUARTE, M.C.T.; FIGUEIRA, G.M.; SARTORATTO, A.; REHDER, V.L.G.; DELARMELINA, C. Anti-Candida activity of Brazilian medicinal plants. Journal of Ethnopharmacology, v.97, p.305-311, 2005.

HOLANDA PINTO, S.A.; PINTO, L.M.; CUNHA, G.M.; CHAVES, M.H.; SANTOS, F.A.; RAO, V.S. Antiinflammatory effect of alpha, beta-amyrin, a pentacyclic triterpene from Protium heptaphyllum in rat model of acute periodontitis. Inflammopharmacology v.16, p.48-52, 2008.

MAIA, R.M.; BARBOSA, P.R.; CRUZ, F.G.; ROQUE, N.F.; FASCIO, M. Triterpenos da resina de Protium heptaphyllum March (Burseraceae): Caracterização em misturas binárias. Química Nova, v.23, p. 623-626, 2000.

MISHRA, B.B.; TIWARI, V.K. Natural products: An evolving role in future drug Discovery. European Journal of Medicinal Chemistry, v.46, p.4769-4807, 2011.

MUSA, M.A.; COOPERWOOD, J.S.; KHAN, M.O. A review of coumarin derivatives in pharmacotherapy of breast cancer. Current Medicinal Chemistry, v.15, p.26642679, 2008.

NCCLS- National Committee for Clinical Laboratory Standards - Padronização dos Testes de Sensibilidade a Antimicrobianos por Disco-difusão: Norma Aprovada - 8ed., v. 23, 2003.

OLIVEIRA, N.A.; AMARAL, I.L. Florística e fitossociologia de uma floresta de vertente na Amazônia Central, Amazonas, Brasil. Acta Amazônica, v.34, p.21-34, 2004.

OTUKI, M.F.; VIEIRA-LIMA, F.V.; MALHEIROS, A.; YUNES, R.A.; CALIXTO, J.B. Topical antiinflammatory effects of the ether extract from Protium kleinii and alpha-amyrin pentacyclic triterpene. European Journal of Pharmacology, v.507, p.253-259, 2005.

PALOMINO; J.C.; MARTIN, A.; CAMACHO, M.; GUERRA, H.; SWINGS, J.; PORTAELS, F. Resazurin Microtiter Assay Plate: simple and inexpensive method for detection of drug resistance in Mycobacterium tuberculosis. Antimicrobial Agents and Chemotherapy, v.46, p.2720-2722, 2002.

RAMOS, M.F.S.; SIANI, A.C.; TAPPIN, M.R.R.; GUIMARÃES, A.C.; RIBEIRO, J.E.L.S. Essential oils from oleoresins of Protium spp. of the Amazon region. Flavour and Fragrance Journal, v.150, p.383-387, 2000.

SANTANA, A.I.; VILA, R.; ESPINOSA, A.; OLMEDO, D.; GUPTA, M.P.; CAÑIGUERAL, S. Composition and biological activity of essential oils from Protium confusum. Natural Products Communication, v.4, p.1401-1406, 2009.

SANTIN, J.R.; LEMOS, M.; KLEIN-JÚNIOR, L.C.; MACHADO, I.D.; COSTA, P.; DE OLIVEIRA, A.P.; TILIA, C.; DE SOUZA, J.P.; DE SOUZA, J.P.B.; BASTOS, J.K.; DE ANDRADE, S.F. Gastroprotective activity of essential oil of the Syzygium aromaticum and its major component eugenol in different animal models. NaunynSchmiedeberg's Archives of Pharmacology, v.38, p.149-158, 2011.

SIANI, A.C.; GARRIDO, I.S.; MONTEIRO, S.S.; CARVALHO, E.S.; RAMOS, M.F.S. Protium icicariba as a sourse of volatile essences. Biochemical Systematics and Ecology v.32, p.477-489, 2004.

SILVA, J.R.A.S.; ZOGHBI, M.G.B.; PINTO, A.C.; GODOY, R.L.O.; AMARAL, A.C.F. Analysis of the hexane extracts from seven oleoresins of Protium species. Journal Essential Oil Research, v.21, p.305-308, 2009.

SIMÕES, C. M. O. (Org.). Farmacognosia: da planta ao medicamento. 6ed. Porto Alegre: Editora da UFRGS, 2007.

SUSUNAGA, G.S.; SIANE, A.C.; PIZZOLATTI, M.G.; YUNES, R.A.; MONAACHE, F.D. Triterpenes from the resin of Protium heptaphyllum. Fitoterapia, v.72, p.709-711, 2001.

TAYLOR, P.; ARSENAK, M.; ABAD, M.J.; FERNÁNDEZ, A.; MILANO, B.; GONTO, R.; RUIZ, M.C.; FRAILE, S.; TAYLOR, S.; ESTRADA, O.; MICHELANGELI, F. Screening of Venezuelan medicinal plant extracts for cytostatic and cytotoxic activity against tumor cell lines. Phytotherapy Research, v.27, p.530-539, 2012.

VALGAS, C.; SOUZA, S.M.; SMÂNIA, E.F.A.; JÚNIOR, A.S. Screening methods to determine antibacterial activity of natural products. Brazilian Journal Microbiology, v.38, p.369-380, 2007.

ZOGHBI, M.G.B.; SIQUEIRA, J.B.G.; WOLTER, E.L.A.; JÚNIOR, O.L.P. Constituintes químicos de Protium paniculatum (BURSERACEAE). Acta Amazônica v.23, p.187-189, 1993.

World Health Organization (WHO). WHO Guidelines on Agricultural and Collection Practices (GACP) for Medicinal Plants. World Health Organization Geneva. 2003. 